new means of winning the collaboration and not just the acquiescence of students in forward planning. The third class of problems is probably not a problem at all but something that universities will have to live with. Indeed, the most surprising feature of university politics is that universities have usually been much less concerned with the problems of the societies in which they are embedded than they could or even should be. Outsiders often find them irritatingly indifferent to the real world and it will be no bad thing if the reawakening of political interest among students turns out to be a brash foretaste of a more solid concern for contemporary problems in the universities as a whole. In this respect, British universities are more backward than those in the United States (where faculty members commute to Washington very often) and Eastern Europe.

So what is to be done? The most immediate need for change is in the relationship between students and the university machine. The strength of the report of the Faculty Student Commission at Berkeley is that it suggests ways in which students can be fitted into the apparatus for making decisions at all levels on the campus. The object, the report argues, is not so much to create formal apparatus by which the conflicting interests of students and the faculty can be brought into confrontation, but rather to create machinery which will somehow remind both sets of people of their mutual interest in a smoothly functioning machine for teaching. It remains, of course, to be seen how much of the commission's report will eventually be embodied in the constitution of the University of California, but the mere fact that it has been written is historic in itself. In Britain, the nearest tangible step in this direction is that taken at the London School of Economics, where students are to be appointed to a number of committees but specifically not the committees concerned with academic policy, and there are some reasons to believe that other universities will follow suit. The trouble, of course, is that it will take time for students to appreciate that devices like these can serve as real instruments of power and possibly even longer for teachers to learn by experience that students have helpful as well as interesting things to say. And in the long run, of course, it is hard to see how students can be entirely excluded from academic policy. It is no longer sensible for the faculty to attempt to buy off students with tea and muffins in the afternoon and sherry before dinner. Until all these things are acknowledged, tension and trouble are likely to persist.

\section{Discussions in Paris}

THE ministerial meeting organized last week in Paris by the Organization for Economic Cooperation and Development seems to have been the sort of success these meetings generally are. The meeting, attended by ministers of science and education from most of the OECD countries, discussed problems of the technological gap, of fundamental research policy and of information retrieval and dissemination. $\mathrm{Mr}$
Patrick Gordon Walker, the British Secretary of State for Education and Science, agreed after the meeting that some progress had been made. In particular, it seems that one of his own suggestions met with some enthusiasm. This was a proposal for the establishment of a European Research Council similar in nature to the ones which operate in Britain.

The funds for such an agency would be provided by what the background paper to the conference calls a "matching fund". This would presumably involve the contributions of sums of money to a central organization from the countries of OECD. The money would then be distributed to existing research groups in OECD countries. As Mr Gordon Walker pointed out, "It would involve a central agency. I am sure that such an agency must be composed mainly of scientists and have autonomy in the arrangement of its business and the disposal of whaterer funds it may have at its command." The beauty of the idea as far as Europe is concerned is that it would not involve the formation of any new institutions; as the background paper points out, it would instead encourage the development of existing research groups of outstanding quality. The paper suggests two fields in which experiments might be carried out, computer science and neurobiology and psychobiology. The meeting in Paris agreed that a serious study of the setting up of such a research council in Europe should be carried out during the next year.

The meeting also spent some time discussing the technological gap between the United States and other OECD countries. The background paper makes a determined effort to define the gaps, concluding that the term can be taken to include almost any feature of life which is different on the other side of the Atlantic. Educational systems, the conditions under which government support is given, the techniques of management, scientific and technological capability and the size and homogeneity of the market in the United States are all quoted as causes of the gap. Given this diversity, it was hardly surprising if the ministers were unable to define easy ways of reducing the gap. $\mathrm{Mr}$ Anthony Wedgwood Benn, the British Minister of Technology, came back to the idea of a European Technological Institute. This time the institute, which has become almost an obsession for British ministers, was described as a means by which Europe could carry out effective long term planning. If Europe could carry out this task of long term market forecasting correctly, Mr Benn said, "it would then be possible to compare the existing need against the capability to meet it". At this point firms would look to their own expansion plans, and see the need for cooperation on a European scale. But Mr Benn made it clear what the technological institute would not beit would not be an academic research institute. "Such laboratories may be desirable for their own reasons, as at CERN, but they do not close any technological gaps."

\section{Gas Bonanza}

The Britjsh Gas Council has at last reached agreement over the price it is prepared to pay for natural gas from the North Sea. So far, the agreement affects only one of the companies lucky enough to discover gas, the Phillips Group. The price agreed is $2.87 d$. a therm, 